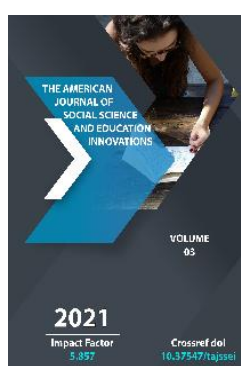

Journal Website: http://usajournalshub.c om/index,php/tajssei

Copyright: Original content from this work may be used under the terms of the creative commons attributes 4.0 licence.

\section{Communication Skills Between The Educational Institution And The Community}

Kubaev A.S. Independent Researcher, Jizzakh Regional Center For Retraining And Advanced Training of Public Educators, Uzbekistan

Nurmanov A.T.

Doctor Of Pedagogical Sciences, Jizzakh State Pedagogical Institute, Uzbekistan

\title{
ABSTRACT
}

The article considers that in the performance of the functions of the head of the technical school, vocational school and vocational college, the pedagogical and student community, parents, sponsors also establish practical and emotional communication with the general public.

\section{KEYWORDS}

Technical school, vocational school, vocational college, head of educational institution, team upbringing, communication culture, pedagogical team.

\section{INTRODUCTION}

The communicative activity of the heads of educational institutions is focused on the performance of certain tasks. These tasks include the establishment of informational, practical and emotional communication with the pedagogical and student community, parents, sponsoring organizations and the general public.

The communicative activity of the leader is to establish informational communication with the participants who need to be 
communicated in the educational process, to organize the educational process, to increase the effectiveness of educational work, social reforms carried out in the country to increase the mental, moral and physical potential of students, the tasks set by higher education institutions, instructions on the organization of spiritual and educational activities in certain areas, as well as receiving and transmitting information about social events of national importance. Information (information) is received by the supervisor in the form of text orally or in writing and communicated to the participants of the educational process in the same forms. The manager who receives the different information should express his / her attitude towards them; can represent the effect. If there are any discrepancies in the information, it is necessary to contact the sender to fill them out and get detailed information, while ensuring the proper functioning of the educational institution, to prevent distraction from the main work of the teaching staff; as well as the general possibility that time wasted will be eliminated.

\section{THE MAIN FINDINGS AND RESULTS}

A model of information connection in communication

G. Lassuella [1:31-61] describes the establishment of information communication in the communication process by the following model:

1) Delivery of information (who delivers?);

2) The content of the information (what is delivered?);

3) Method of data transmission (how is it transmitted?);

4) Receiving information (who receives?).
The manifestation of the leader's communicative activity as a practical connection allows establishing direct, active communication with the pedagogical and student community, to unite them around a single goal of the educational institution, to identify measures to make full use of existing opportunities, to increase the effectiveness of educational and spiritual work. creation of conditions (including involvement in the institution of specialists who have mastered the basics of special disciplines, sufficiently aware of pedagogical, psychological and methodological knowledge, introduction of advanced pedagogical technologies in the educational process, control over adequate supply of educational resources, strengthening the material and technical base etc.).

This type of communicative activity is the analysis of the personal activity of the leader, the elimination of mistakes; the possibility of manifestation in the psyche is also reflected in the action aimed at preventing the intended depression, psychological and physical stress.

The practical communication in the communicative activity of the head of the educational institution creates a favorable environment for analyzing the reasons for team interaction, professional and educational needs, common goals, organizational and pedagogical tasks, taking into account the mutual capabilities of team members and the implementation of tasks. The effectiveness of these tasks is determined by joint activity and communication, as well as satisfaction with its results.

Clearly defined situations of the subjects in the communicative activity, which creates an emotional connection between the leader and the participants of the educational process; 
thus representing the nature of the changes that occur during involuntary, random effects.

Usually people get rid of negative influences during communication, forgetting the problems and worries that bother them; on the contrary, they hope that there will be a need to live within them, to strive for life anew. After all, the worldview, life aspirations of the subjects whose essence, direction and interaction are; the level of knowledge has the property of enhancing or relieving the psychological tension of communication according to the relationship with others.

From a psychological point of view, communication based on the activities of the educational institution can be effective only if the subjects involved in it achieve their goals and there is no feeling of dissatisfaction in the leader, pedagogical or student community, parents, sponsors. The effectiveness of communication, as many think, depends not only on the mental, emotional and volitional abilities of the participants. On the contrary, the extent to which they can understand, support, and help each other materially or spiritually ensures the effectiveness of this process.

Problems in the management of the head of the educational institution

The ineffective completion of the process of communicative communication between the head of the educational institution and his subordinates and the emergence of psychological conflicts in it are caused by the following:

1) Inconsistency of goals;

2) Insufficient assessment of the abilities, interests and capabilities of the teacher or students by the supervisor;
3) Incorrect acceptance of the relationship of subordinates;

4) Incorrect assessment of personal capabilities by the manager;

5) Incorrect choice of communication methods for specific situations;

6) Insufficient mastery of communication techniques by the manager;

7) Lack of social awareness of the leader.

If the communicative activity of the head of the educational institution is considered as a general process, it has two main parts, namely: can be seen to consist of reference and practical parts.

1. The effectiveness of the referral part in turn leads to the effective completion of the overall communication process. The lack of mutual understanding between the leader and his subordinates leads to the ineffective conclusion of this part.

2. The practical part of communicative activity is the choice of methods of communication by the participants of the educational process, the expression of personal views on a particular issue. Hence, it is self-evident that the wrong choice of communication methods by the leader, the inability of subordinates to express their views clearly, succinctly and concisely in the process of communication leads to the ineffective completion of the practical part.

Another challenge a leader faces in organizing communicative activities is that the learning process involves different age groups of participants. Consequently, the presence of individuals with little or no life experience in the pedagogical and student community, as well as among parents, leads to conversations on specific topics; creates certain difficulties in 
organizing roundtables and meetings (academic lyceum, technical school, vocational school and vocational college general meeting, parent meeting, student team meeting, group meeting, etc.).

The head of the educational institution should be able to take into account the profession of science teachers, their age, psychological characteristics in communication with the student body. The main focus should be on taking into account the typical characteristics specific to different age groups, their abilities and capabilities. Most teachers, including leaders, prefer to rely on an authoritarian style in communicating with the student body and try to prove the correctness of such behavior in terms of national mentality, spiritual and moral views. However, as a result of extensive research conducted in recent years by A.lbrahimov, H.Sultonov, N.Juraeva,
M.Bekmurodov, I.Imomnazarov, I.Safarbuvaeva and others, the authoritarian approach to young people has led to their independence, personal opinion. it has been found that it impedes the development of qualities such as free expression, in which dependence leads to the formation of muteness.

The main focus in the organization of communication by the head of the educational institution should be to create a healthy psychological environment in the teaching staff.

At the same time, understanding the essence of the concepts of "pedagogical community" and "healthy psychological environment" allows to adequately assess the social and psychological benefits of an environment based on mutual unity and support in educational institutions.
First of all, it is expedient to understand the essence of the concept of "team". In pedagogical sources, this concept is defined as follows: a community (translated from the Latin word "|collectivus", a gathering, community, joint meeting, association, group) is a group of several members (persons) formed on the basis of a common goal of social significance [2:198]; a specific group of people doing the same job [2:68].

At this point, we agreed with the authors that it is necessary to pay special attention to the fact that according to the formation and existence of the team can be divided into groups such as a temporary team and a stable team. A temporary team is formed for a certain period of time to achieve a specific goal. For example, a team that is united or consolidated for the purpose of performing seasonal work or military service is considered to be a temporarily formed team. The temporary organization is mainly carried out by shortterm activities. Long-term activity is typical for a stable team. The length and brevity of the activity is important for the team. During the period of long-term activity, the subjects who are members of the team will have the opportunity to get to know each other better, to understand each other. For members of a temporary team, the time required to complete the activity does not allow them to get to know each other better.

This source, created by the team of authors, focuses on the use of the term "team" in two different senses. That is, first, a team is an organizational group consisting of several people united in a specific goal path (e.g., production team, factory team, college team, farm team, etc.). Second, a team is a highly organized group. 
The following characteristics of the team increase its educational potential:

1) That any community is part of a particular social community;

2) Any team has a clear, single goal;

3) The ability of any team to interact or collaborate with many other teams;

4) Ownership of the governing body of any team;

5) Implementation by any community of activities aimed at meeting the social needs of society;

6) The socio-ideological content of the activities organized by any community;

7) The ability of any team to have a strong influence on the behavior, inner experiences, life goals and aspirations and behaviors of its members.

Leaders of technical schools, vocational schools and vocational colleges must be able to fully and correctly understand these characteristics of the team in the organization of team management. After all, their correct understanding ensures that team leadership is carried out methodologically in accordance with the purpose. Proper organization of team management also helps to determine the "team spirit, in particular, the mutual intimacy, diligence, mutual care, mutual assistance, concern for the interests of the community, the organization of practical actions and a sense of responsibility". "Collaborative work instills a sense of responsibility for community work, brings team members closer together, helps members develop a sense of belonging to the community, and increases the need to interact with the community. There is a mutual emotional unity (feeling of liking each other) among the members of the team" [3:199-200].
Pedagogical sources emphasize that the structure of the team, in particular, its formal (business) or informal (emotional) status, also serves to highlight the nature of management activities organized by the leader to coordinate the actions and aspirations of team members.

\section{CONCLUSION}

If we interpret it from the point of view of the research problem, it becomes clear that the pedagogical team is an association of specialists with pedagogical and psychological knowledge, united in the pursuit of specific educational goals. The level of organization of the pedagogical team depends on the communicative and organizational skills of the person leading the educational institution.

Improper communicative activity of the head of the educational institution creates mutual mistrust, anxiety and insecurity in the implementation of professional activities in the teaching staff, diverts teachers' attention from the implementation of educational goals, and impairs the ability to work. As a result, the pedagogical team is divided into small groups, there are disagreements and contradictions. Disagreements and contradictions in the pedagogical community inevitably have a negative impact on the educational process. Certain negative relationships that occur in the pedagogical community can take a long time to form.

\section{REFERENCES}

1. Karimov I.A. (1997). "National training program of the Republic of Uzbekistan" // Harmoniously developed generation is the basis of development of Uzbekistan. Tashkent: "Sharq". - pp. 31-61. (Каримов И.А Ўзбекистон Республикасининг “Кадрлар тайёрлаш миллий дастури” 
//Баркамол авлод - Ўзбекистон тараққиётининг пойдевори. - Тошкент: Шарқ, 1997. - 31-61-б.)

2. Axlidinov R.Sh. (2006). The art of school management. -Tashkent. “Fan”. - p. 304. (Ахлидинов Р.Ш. Мактабни бошқариш санъати. -Тошкент, Фан, 2006. -304 б)

3. Mescon M.Kh. Albert M., Hedouri F. (1995). Fundamentals of Management // Translated from English. - Moscow: Delo LTD. - p. 704. (Мескон М.Х. Альберт М., Хедоури Ф. Основы менеджмента//Пер. с англ. -М.: Дело ЛТД, 1995. -704 с.)

4. Annotated dictionary of the Uzbek language. Volumes 1-5. - Tashkent: National Encyclopedia of Uzbekistan, 2006-2008. (Ўзбек тилининг изохли луғати. 1-5 жилдллар. - Т: ЎзМЭ, 20062008.)

5. Ishmuhamedov R., Abduqodirov A., Pardaev A. (2007). Director's workbook (practical recommendations). - Tashkent: "Istedod". - p. 121. (Ишмухамедов P., Абдуқодиров А., Пардаев А. Директорнинг иш китоби (амалий тавсиялар). - Т: “Истеъдод”, 2007. - 121 б.)

6. Farfieva K. A. Social Media as a factor in formation of scientific thinking in youth. European Journal of Research and Reflection in Educational Sciences. Vol. 8 No. 10, 2020. - Pp. 52-56. 